\title{
ORAL HEALTH AND SALIVARY PROFILES OF GERIATRIC OUTPATIENTS IN CIPTO MANGUNKUSUMO GENERAL HOSPITAL
}

\author{
Aji Kurniawan ${ }^{1}$, Yuniardini Septorini Wimardhani2*, Febrina Rahmayanti ${ }^{2}$ \\ 1. Program of Bachelor of Dental Science, Faculty of Dentistry, Universitas Indonesia \\ 2. Department of Oral Medicine, Faculty of Dentistry, Universitas Indonesia \\ *E-mail: yswimardhani@yahoo.com
}

\begin{abstract}
Introduction: Population of geriatric patients would increase in line with that of elderly population. Health problems related to this group of people would have impact on general and oral health maintenance aiming for good quality of life. Objectives: This study aimed to determine the profile of oral health, saliva, and oral mucosa on geriatric patients at Geriatric Policlinic in Cipto Mangunkusumo Hospital. Materials and Methods: This research was a descriptive crosssectional study, which data was taken using questionnaire containing basic demographical information and oral clinical examination using standard form used by Faculty of Dentistry Universitas Indonesia. Results: The study included 75 geriatric patients, ranging from 60 to 86 of age. The mean of DMF-T score of 69 geriatric patients was $4.68 \pm 2.893$, OHI-S $2.790 \pm 1.102$, PBI $0.779 \pm 0.585$. The mean of unstimulated salivary $\mathrm{pH}$ score was $6.618 \pm 0.54$ and stimulated buffer capacity of saliva was $7.46 \pm 2.827$. Mean of salivary flow rate is $0.24 \mathrm{~mL} / \mathrm{min}$ and 39 people had hiposalivation. 93 normal variations and 117 pathological oral lesion was found. Conclusion: This study showed that poor oral health status and pathological oral lesion found in this study elderly population could be caused from poor salivary flow, $\mathrm{pH}$ saliva, and buffer capacity of saliva. Systematic oral examination of the elderly is of considerable importance and ought be carried out regularly by a dentist in collaboration with the physician; making holistic management of the elderly properly performed.
\end{abstract}

\begin{abstract}
Abstrak
Pendahuluan: Profil Kesehatan Mulut dan Saliva pada Pasien Geriatri di Rumah Sakit Cipto Mangunkusumo. Pasien geriatri meningkat sejalan dengan peningkatan populasi Lansia. Permasalahan kesehatan umum dan gigi-mulut akan mempengaruhi kualitas hidup mereka. Tujuan: Studi ini bertujuan untuk mendeskripsikan kesehatan gigi dan mulut secara menyeluruh pada pasien geriatri di poliklinik geriatri di Rumah Sakit Cipto Mangunkusumo. Bahan dan Cara: penelitian ini adalah studi deskriptif. Kuesioner digunakan untuk mendapatkan data demografik. Pemeriksaan klinis intreoral dilakukan berdasarkan standar Fakultas Kedokteran Gigi Universitas Indonesia. Hasil: Jumlah sampel adalah 75 pasien geriatri dengan usia 60-86 tahun. Rata-rata skor DMF-T adalah 4.68 \pm 2.89 , OHI-S $2.79 \pm 1.10$, PBI $0.78 \pm 0.59$. Rata-rata skor unstimulated salivary $p H 6.62 \pm 0.54$ dan stimulated buffer capacity saliva $7.46 \pm 2.83$. Ratarata laju aliran saliva adalah $0,24 \mathrm{~mL} / \mathrm{menit}$ dan hiposalivasi ditemukan pada 39 orang. 93 variasi normal dan 117 lesi patologis ditemukan pada studi ini. Kesimpulan: Ditemukannya status kesehatan gigi dan mulut yang rendah pada sampel penelitian ini menunjukkan adanya kemungkinan penyebabnya adalah rendahnya laju alur saliva, $\mathrm{pH}$ saliva, dan kemampuan buffer saliva. Pemeriksaan kesehatan gigi dan mulut secara sistematik dan rutin pada Lansia merupakan hal yang penting dan seyogyanya dilakukan secara holistik dengan kolaborasi antara dokter dan dokter gigi.
\end{abstract}

Keywords: geriatric patients, oral health, salivary flow rate, salivary $\mathrm{pH}$, buffer capacity 


\section{Introduction}

By the year of 2010, the population of elderly who are older than 65 years old in Indonesia are estimated to be thirteen million people and the number would be doubled by $2020 .{ }^{1}$ The increase of the elderly population would almost likely to result in the raising of the number of geriatric patients. The Indonesian Ministry of Health and United Nation classified elderly as people who are more than 60 years old. ${ }^{2,3}$ Indonesia would pose tremendous challenges in health status of this specific population since disease pattern would shift. Degenerative diseases such as cardiovascular disease, hypertension, cancer, and diabetes are prevalent in elderly. ${ }^{3}$

Oral health is one of the important components of aging, due to the presence of oral disease can affect general health and quality of life of elderly people. Major problems found in elderly include oral health and causing impairment in its function. Dental caries, tooth loss, periodontal diseases, xerostomia, and oral precancer/cancer are prevalent among elderly. WHO stated that impairment of all component of physical condition would be apparent in the elderly. Therefore, it would also happen in the oral mucosal condition. Dentist as health professional dealing with oral problems should be aware of the possible diverse condition of oral mucosa in elderly population and making assessment of the condition of oral health should always be integrated to the physical assessment of the elderly to ensure holistic geriatric patient care. ${ }^{4,5}$ Since the condition in the elderly oral mucosa would be complicated by the changes in the physiological, physical as well as the psychological states. $^{5}$ The Indonesian Basic Health Research in 2007 showed that the prevalence of oral health disease in elderly was $22.1 \%{ }^{3}$. Nevertheless, data on oral health in geriatric patients in Indonesia is still limited and scattered. Data presenting this condition would provide basic information for developing health policies especially to this particular population and to the overall population, in order to prevent and manage the existing conditions.

\section{Materials and Methods}

Participants of this study were geriatric patients who were randomly selected from Geriatric Outpatient Clinic, Cipto Mangunkusumo Hospital, Jakarta. The patients were sampled consecutively with a sum of 75 subjects with a six months time of recruitment process. The inclusion criteria were patients with age more than 60 years old, had 4 degenerative diseases in minimum and voluntarily participated the study. The study was approved by the Ethics Committee of the Faculty of Dentistry Universitas Indonesia, Jakarta. At first, demographic information were obtained from the subjects. Them, clinical examination were carried out by several calibrated dentists to note the subjects' oral health. Decayed, Missing, Filled - Teeth (DMF-T) index, Oral Hygiene Index - Simplified (OHI-S), Papilla Bleeding Index (PBI) Unstimulated Salivary Flow Rate (USFR), Stimulated Salivary Flow Rate (SSFR), salivary $\mathrm{pH}$ and salivary buffering capacity were obtained. ${ }^{3}$ The SalivaCheck Buffer Kit (GC America, Inc.) was used to check the salivary $\mathrm{pH}$ and the buffering capacity. The procedure of each measurement was performed according to the manual's instruction.

\section{Results}

Demographic characteristics of the subjects in this study in terms of gender and age are presented in Table 1. The number of female subjects was twice of that of male subjects. The subjects' were ranging from 60 to 86 years of age. The mean, median and mode were 70.2, 70 and 66 years old with standard deviation of 6.20. Almost one fourth $(25 \%)$ of the subjects were in 64-67 years old group and only about $6 \%$ of subjects were older than 80 years old.

Table 1. Descriptive demographic characteristics of samples

\begin{tabular}{ccc}
\hline & Total & Percentage (\%) \\
\hline Gender & & \\
Man & 25 & 33,33 \\
Woman & 50 & 66,67 \\
Age (year) & & \\
$60-63$ & 8 & 10,67 \\
$64-67$ & 24 & 32,00 \\
$68-71$ & 13 & 17,33 \\
$72-75$ & 14 & 18,67 \\
$76-79$ & 10 & 13,33 \\
$80-83$ & 3 & 4,00 \\
$84-87$ & 3 & 4,00 \\
$\mathbf{N}$ & 75 & 100,00 \\
\hline
\end{tabular}

Only sixty-nine of subjects (92\%) were examined to get data on oral health status since the others were already edentulous. The mean and SD data on subjects' oral health status in terms of DMF-T index, OHI-S and PBI were $4.68 \pm 2.89,2.79 \pm 1.10$ and $0.78 \pm 0.59$, respectively (Table 2). High DMF-T index for this population was noted, with $25(36 \%)$ subjects having DMF-T index higher than 5. Poor oral hygiene was also noted in this population group with 35 out of 69 subjects (51\%) were having OHI-S of 3 or higher. However, it was surprising that the mean PBI score for this population was $0.75 \pm 0.56$, since 9 (13\%) of subjects had zero PBI value. This population study 
Table.2 Descriptive statistics of research variables in sampled geriatric patients

\begin{tabular}{lccccc}
\hline Variable & N & Minimum & Maximum & Mean & SD \\
\hline DMF-T & 69 & 0 & 14 & 4,68 & 2,893 \\
OHI-S & 69 & 0 & 4,8 & 2,790 & 1,102 \\
PBI & 69 & 0 & 2 & 0,779 & 0,585 \\
pH & 75 & 5,2 & 7,8 & 6,618 & 0,54 \\
Saliva & & & & & \\
Buffer & 75 & 2 & 13 & 7,64 & 2,827 \\
Saliva & & & & & \\
\hline
\end{tabular}

had moderate salivary $\mathrm{pH}$ (mean 6.62 \pm 0.54 ) and low salivary buffer capacity (7.64 \pm 2.83$)$. Data on the USFR and the SSFR was presented in Table.3. According to the USSFR and SSFR data, 39 subjects (52\%) and 30 subjects (40\%) were classified as having hiposalivation, respectively (Table 3 ).

Table.3 Unstimulated and Stimulated Salivary flow in sampled geriatric patients

\begin{tabular}{|c|c|c|c|c|c|}
\hline \multirow{2}{*}{$\begin{array}{c}\text { Salivary } \\
\text { Flow }\end{array}$} & Minimum & a Maximum & Mean & \multirow{2}{*}{$\begin{array}{l}\text { Hiposa } \\
\text { livation } \\
\text { patients } \\
\text { (N) }\end{array}$} & \multirow{2}{*}{$\begin{array}{c}\text { Percen } \\
\text { tage } \\
(\%)\end{array}$} \\
\hline & & $(\mathrm{mL} / \mathrm{min})$ & & & \\
\hline Unstimulated & 0,01 & 0,80 & 0,24 & 39 & 52,00 \\
\hline Stimulated & 0,08 & 6,40 & 0,97 & 30 & 40,00 \\
\hline
\end{tabular}

Table.4 Oral Mucosal in sampled geriatric patients

\begin{tabular}{lcc}
\hline \multicolumn{1}{c}{ Oral Mucosal } & Total & Percentage(\%) \\
\hline Normal Variation & & \\
$\quad$ Varicosities & 29 & 32 \\
$\quad$ Fissured tongue & 26 & 28 \\
Fordyce granule & 16 & 17 \\
Linea alba & 11 & 12 \\
Cheek biting & 4 & 4 \\
Torus palatinus & 3 & 3 \\
Geographic tongue & 2 & 2 \\
Scallop tongue & 2 & 2 \\
Total & 93 & 100 \\
Pathological Oral Lesion & & \\
Tongue coating & 56 & 47.8 \\
Pigmentation & 22 & 18.8 \\
Athropy tongue & 18 & 15.4 \\
papillae & & 4.3 \\
Mucosal erythema & 5 & 3.4 \\
Frictional keratosis & 4 & 2.7 \\
Ptechiae & 3 & 2.7 \\
Oral ulcers & 3 & 1.7 \\
Denture stomatitis & 2 & 0.8 \\
Erythematous & 1 & 0.8 \\
candidiasis & 1 & 0.8 \\
Candidiasis oral & 1 & 0.8 \\
Mucocele & 1 & \\
Nevus & 117 & \\
Total & & \\
\hline
\end{tabular}

Table 4 summarizes findings after oral mucosal examination. It was recorded as much as 210 oral mucosal findings, which consisted of 93 (44.3\%) normal oral mucosal variations, and 117 (55.7\%) pathological oral lesions. Varicosities $29(32 \%)$ is the most common finding of normal variation in oral cavity of subjects in this study, followed by fissured tongue $26(28 \%)$, fordyce granules $16(17 \%)$, linea alba $11(12 \%)$. Other normal oral mucosal variations such as cheek biting, torus palatinus, geographic tongue, and scallop tongue were also found (Table 4). Tongue coating was the most prevalent pathologic oral mucosal findings accounted for almost $50 \%$ of all pathologic findings (Figure. $1 \mathrm{~b}$ ), with approximately $75 \%$ of subjects were having this condition. Approximately $30 \%$ of subjects were having pigmentation in the oral mucosa (Figure. 1a). Atrophic tongue papilla was found in 18 subjects (15\%) (Figure.1d). Other oral pathologic conditions such as mucosal erythema, ptechiae, oral ulceration, denture stomatitis (Figure. 1c), erythematous candidiasis, frictional keratosis, oral candidiasis, mucocele, and nevus were also found.
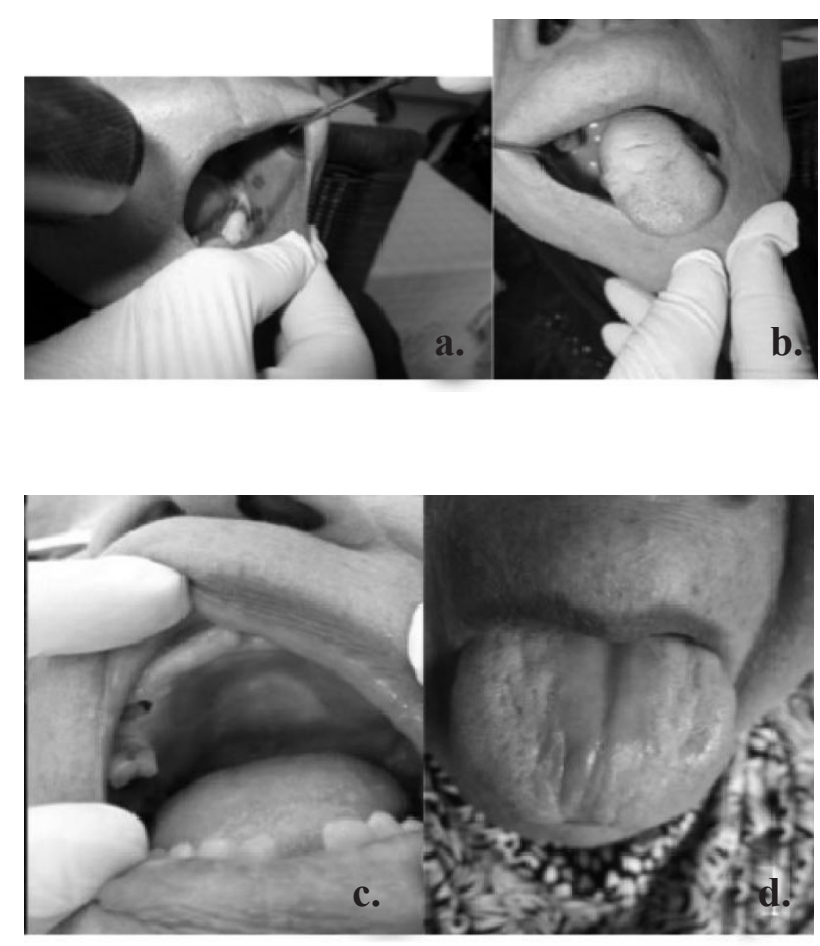

Figure 1a. Pigmentation, b. Tongue coating, c. Denture stomatitis and d. Atrophic tongue papillae

\section{Discussion}

Changes in the oral mucosa would be noticeable in the elderly. ${ }^{6}$ Thinning of the epithelial lining of the mucosa would prone the elderly individuals to injury, which then results in reduced stomatognatic system. ${ }^{6}$ These conditions would have impact to the condition of the oral 
mucosa. This study revealed that the profile of oral health of geriatric patients of the Cipto Mangunkusumo Hospital Geriatric Outpatient Clinic in terms of DMF-T index and OHI-S was similar of that of Indonesian Basic Health Research in 2007. ${ }^{7}$ The high DMFT index score presented high prevalence of dental caries. This study did not analyze root caries, therefore this study did not have data regarding the prevalence of caries in exposed root surface that is more prevalent in elderly. ${ }^{8}$ Poor oral hygiene was also the main finding of the samples. This might be caused by the reduced ability in performing oral hygiene practices. Delays in cleaning the oral environment could be as a result of impaired general health which might also decreased salivary flow. ${ }^{8,9}$ Many of subjects in this study stated brushing their teeth once a day. This study also revealed high prevalence of hyposalivation in the subjects based on the USSFR and SSFR values (Table 3), which might also explain the high prevalence of caries in the subjects. Dental caries occurrences might also be caused by $\mathrm{pH}$ and buffering capacity of the saliva (Table 2). Reduced salivary $\mathrm{pH}$ and buffering capacity in the samples were considered moderate to low, causing caries in this population was more likely to happen.

Interestingly, although majority of the subjects had poor oral hygiene, the PBI score was categorized as good. Almost $80 \%$ of subjects had PBI score less than 1.3, whose $16 \%$ of them having no bleeding on probing. Usually, PBI score would be positively correlated with oral hygiene condition, however this study revealed the contrary. Possible explanation of this phenomenon could be the change in the composition of mucosal tissue of the gingiva in the elderly. Less vascularisation might be one of the cause, however many studies have shown that the elderly are prone to oral mucosal infections with tendencies to delays in healing as a result of decreased immune system. ${ }^{10}$ The manifestation of chronic disease and drugs that are regularly intake of elderly could change their immune system to respond the condition. The other possible explanation was that high prevalence of tooth loss in elderly causing the measurement of PBI not taken optimally according to the measurement standard.

Findings of oral diseases in elderly should be taken seriously, since they might cause dramatic impact on them such as pneumonia, bacteremia, infective endocarditis, coronary artery disease, brain abscesses and other serious consequences. ${ }^{10,11}$ Proper dental health education and referral to dental clinics were performed in the subjects after completion of dental examination.

A number of normal oral mucosal variations were found in this study population (Table 4). Similar to previous studies, sublingual varicosities were the most frequently in observed alteration ${ }^{12}$, they are acquired and benign condition, and their incidence increases with age. ${ }^{13}$ Other variations observed were fordyce granules, linea alba, cheek biting, torus palatinus, geographic tongue, and scallop tongue. After finding of these conditions, subjects were informed about their presence and their possible impact on their general and oral health.

High prevalence of tongue coating was found, which reflects the low oral health maintenance of the elderly. Possible side effects of many medications regularly taken by the subjects might also affect the presence of tongue coating. ${ }^{12}$ Pigmentation, atrophic tongue papillae, mucosal erythema, ptechiae, oral ulcerations, denture stomatitis, erythematous candidiasis, frictional keratosis, candidiasis oral, mucocele and nevus were found as well. Proper information, education and treatment related to the findings of the oral mucosal pathologic conditions in the subjects of this study were then performed.

This study showed that poor oral health and high number of oral mucosal lesions were frequently found in the geriatric patients. Therefore, systematic oral examination of the elderly is of considerable importance and ought to be carried out regularly by dentists ${ }^{5}$ in collaboration with the physician. Performing holistic health management of elderly shall be conducted in all times. Regular oral examination by general practitioners or specialists and regular oral health education should be part of the medical care provided to elderly. Finally, oral health condition in elderly are highly related to their quality of life. This is an important public health issue which must be addressed by policy makers, by developing proper health programs for elderly. Proper management of the aging population would reduce the problems of many ailments that affect this population group.

\section{Acknowledgement}

We would like to thank the Department of Internal Medicine Sub Division of Geriatric Medicine Staff, Drs. Ahmad Ronal and Indriasti Indah Wardhany for supporting this study. This study was partly funded by Hibah Riset Awal Universitas Indonesia 2010.

\section{References}

1. Kementrian Kesehatan RI. Profil Kesehatan Indonesia. 2009. Jakarta: Depkes. 2010.

2. Departemen Kesehatan \& Kesejahteraan Sosial RI. Pedoman Pembinaan Kesehatan Jiwa Usia Lanjut Bagi Petugas Kesehatan. Jakarta: Depkes. 2001.

3. World Health Organization. Improving Oral Health 
Amongst The Elderly. http://www.who.int/oral_health/ action/groups/en/index 1.html. cited 16/10/2011.

4. Taiwo JO, Kolude B, Akinmoladun V. Oral mucosal lesions and temporomandibular joint impairment of elderly people in the South East Local Government Area of Ibadan. Gerodontology 2009; 26:291-24.

5. Yeh C, Katz MS, Saunders MJ. Geriatric Dentistry: Integral Component to Geriatric Patient Care. Taiwan Geriatrics \& Gerontology 2008; 3:182-92.

6. Klein DR. Oral soft tissue changes in geriatric patients. Bull NY Acad Med 1980; 56:721-7.

7. Badan Penelitian dan Pengembangan Kesehatan Depkes RI. Laporan Hasil Riset Kesehatan Dasar (RISKESDAS) Nasional 2007. www.pdfio. com/k-314627.html cited 10/11/2011.

8. Henriksen BM, Ambjornsen E, Axell T. Dental caries among the elderly in Norway. Acta Odontol Scand 2004; 62: 75-81.

9. Jorgensen et al. Caries prevalence and associated predisposing conditions in recently hospitalized elderly patients. Acta Odontol Scand 1996; 54:251-6.

10. Ship JA. 'Geriatrics' In Burket's Oral Medicine, Diagnosis and Treatment. $10^{\text {th }}$ ed. Canada, B C Decker Inc., 2003: p 605-22.

11. Shay K. Dental management considerations for institutionalized geriatric patients. J Prosthet Dent 1994; 72: 510-6.

12. Raquel CF, Allyson NM. Oral Mucosal Alterations among Institutionalized Elderly in Brazil. Braz Oral Res. 2010; 24(3): 296-302.

13. Cawson RA. Oral Pathology and Oral Medicine. 7th ed. 2002, London: Elsevier Science Ltd. 